\title{
САНАЦІЯ ПОВІТРЯ ВІВАРІЮ ЗА ДОПОМОГОЮ УЛЬТРАФІОЛЕТОВОГО ОПРОМІНЮВАННЯ
}

\section{Рецензент - доктор ветеринарних наук А. А. Замазій}

Наведена можливість використання ультрафіолетового бактерицидного опромінювача-

рециркулятора закритого типу «Фіолет-Т04» для саначії птахівничих приміщень за наявності птиці. Визначено оптимальні режими роботи опромінювача та можливість його застосування в процесі санації повітря птахівничого приміщення. Крім того визначено бактерицидну дію ультрафіолетового опромінювача на загальну мікробну забрудненість повітря віварію (кількість мікроорганізмів у повітрі знизилася на $28 \%$ ) та відсутність негативного впливу на птицю. Збереженість поголів'я становила $100 \%$.

Ключові слова: ультрафіолет, опромінювач, перепели, птахівниче приміщення, мікробне забруднення, саначія, знезаражуюча дія.

Постановка проблеми. Для промислового птахівництва характерна висока концентрація птиці на невеликих територіях, поточна система вирощування, збільшення щільності посадки у пташниках, що викликає нагромадження i peциркуляцію хвороботворних мікроорганізмів (із посиленням їхніх патогенних властивостей), токсичних газів та пилу у повітрі. Це призводить до погіршення збереженості і продуктивних показників птиці та загрожує іiі ветеринарносанітарному благополуччю (Дуюнов Е. Е., 2006).

У сучасному птахівництві в процесі проведення ветеринарно-санітарних заходів незначна увага приділяється екологічним методам дезінфекції (санаціі).

Перевага надається хімічним дезінфектантам, що швидко діють на патогенні мікроорганізми, але за своєю дією вони агресивні. Їхні залишки можуть завдати шкоди не тільки птиці, а й обслуговуючому персоналу, i це $є$ значним недоліком.

Для зменшення мікробного забруднення повітря за наявності птиці найчастіше використовують аерозольний метод дезінфекції, що передбачає обробку об'єктів частинками діючої речовини розмірами від 0,5 до 50 мікрометрів. Ці час- тинки можуть протягом тривалого часу (близько 3-4 годин) знаходитись у приміщенні у завислому стані, мають досить значну сумарну поверхню і проникаючу здатність, що значно підвищує ефективність застосування дезінфектанту та якість дезінфекції (Дуюнов Е. Е., 2006). Водночас при застосуванні дезінфектантів (навіть допущених до використання за наявності птиці) завжди існує небезпека їх негативного впливу як на птицю, так і на продукцію (м'ясо та яйця), а також довкілля (Савост'янова К. В., 2009).

Тому пошук більш безпечних способів зменшення мікробного забруднення пташників залишається актуальною проблемою.

Аналіз основних досліджень і публікацій, у яких започатковано розв'язання проблеми. Відповідно до «Ветеринарно-санітарних правил для птахівницьких господарств i вимог до їх проектування», гранично допустимою концентрацією (ГДК) мікроорганізмів у повітрі пташників для вирощування ремонтного молодняку птиці в кліткових батареях $є 100$ тис. мікробних тіл в $1 \mathrm{~m}^{3}$, утримання дорослої птиці в кліткових батареях -220 тис. мікробних тіл в $1 \mathrm{~m}^{3}$ [2].

Як показують дослідження, проведені в Сумському аграрному університеті, кількість мікроорганізмів у повітрі пташника при утриманні курейнесучок уже через три місяці після його дезінфекції й посадки птиці в пташник сягало 1 млн м. т. $/ \mathrm{m}^{3}$, а через 12 місяців - 6 млн м. т./ $\mathrm{m}^{3}[1]$.

На даний час мікроорганізми знешкоджують, в основному, проведенням дезінфекції в період профілактичних перерв, при заміні птиці та санації пташників. Однак, як свідчать наукові дослідження, однієї такої дезінфекції нерідко буває недостатньо, тому що в процесі своєї життєдіяльності птиця сама є генератором мікрофлори; мікроорганізми розповсюджуються аерогенним шляхом, обслуговуючим персоналом, комахами, гризунами тощо. Тому мікробне забруднення пташників протягом усього періоду вирощування й утримання птиці зазвичай поступово

*Керівник-кандидат ветеринарних наук С. Б. Передера 
збільшується і часто перевищує встановлені ветеринарно-санітарними правилами для птахівничих підприємств гранично допустимі концентрації [4].

Деякими технологічними інструкціями і настановами 3 проведення ветеринарно-санітарних заходів у пташниках для зменшення мікробного «тиску» пропонується проводити дезінфекцію пташника або санацію повітря за наявності птиці. Проте рекомендації з таких обробок не конкретизовані щодо способів і режимів їхнього проведення для різних видів і технологічних груп, не вивчено їхній вплив на збереженість і продуктивність птиці [4].

В Інституті птахівництва УААН було проведено дослідження 3 обгрунтування режимів дезінфекції повітря у пташнику за наявності птиці в процесі вирощування бройлерів на підлозі за допомогою ультрафіолетового випромінювання бактерицидного діапазону. Кращі результати було отримано за застосування режиму роботи бактерицидних ламп - 8 разів на добу по 7,5 хвилин. Загальна доза опромінення за добу ста-

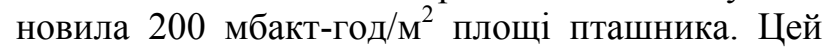
режим дав змогу зменшити середній рівень мікробного забруднення повітря в 1,9-2,3 рази й сприяв підвищенню живої маси бройлерів у семитижневому віці на 12,9 \% порівняно з бройлерами, у вирощуванні яких аналогічна дезінфекція не виконувалася [4].

Максимальною бактерицидною активністю володіє випромінювання 3 довжиною хвилі у діапазоні 200-280 нанометрів. Понад 78 \% усього електромагнітного випромінювання на цей діапазон припадає у бактерицидних ламп. Ультрафіолетове випромінювання, особливо ерітемної ділянки спектру, в певних дозах позитивно впливає на фізіологічний стан птиці $[5,7]$.

Мета і завдання досліджень. Мета - визначити знезаражуючу дію опромінювача щодо мікроорганізмів, що знаходились у повітрі пташника. Завданням наших досліджень було визначити можливість використання бактерицидного опромінювача-рециркулятора закритого типу для санації повітря птахівничих приміщень за наявності птиці, а також довести відсутність негативного впливу на неї.

Матеріали і методи досліджень. Дослідження проводилися в період із червня 2011 р. по грудень 2011 р. в приміщенні віварію 3 клітковим утриманням дорослих перепелів на базі Полтавської державної аграрної академії (м. Полтава). Проводили мікробіологічні дослідження повітря віварію, зокрема визначали зага- льну мікробну забрудненість повітря в разі використання ультрафіолетового бактерицидного опромінювача-рециркулятора «Фіолет-Т04». Проби повітря відбирали до і після санації.

Об'єкт дослідження - бактеріальне забруднення повітря та перепели, які утримувались у клітках. Предмет досліджень - ультрафіолетовий бактерицидний опромінювач-рециркулятор закритого типу «Фіолет-Т04».

Для санації повітря приміщення віварію використовували ультрафіолетовий бактерицидний опромінювач-рециркулятор закритого типу «Фіолет-Т04». Об'єм знезаражуваного повітря, що проходить крізь один опромінювач-рециркулятор, становить $85 \mathrm{~m}^{3}$ за годину.

Два опромінювача «Фіолет-Т04» встановили в приміщенні 3 клітковим утриманням перепелів. Їх розмістили на стіні, у вертикальному положенні на висоті 1,5 м від підлоги. Забір і вихід санованого повітря здійснювався безперешкодно й співпадав із напрямом основних конвекційних потоків. Об'єм приміщення - $105 \mathrm{~m}^{3}$. За допомогою таймеpa, яким обладнані рециркулятори, встановлювали режими обробки повітря по 35 і 75 хвилин. За цей час опромінювані-рециркулятори знезаражували $105 \mathrm{~m}^{3}$ повітря та $210 \mathrm{~m}^{3}$ відповідно. За першого режиму повітря приміщення обробилось ультрафіолетовими променями одноразово, а при другому - дворазово.

Результати досліджень. Результати досліджень (табл. 1) показали, що за першого (одноразового) режиму санації повітря (35 хв.) ультрафіолетовим бактерицидним опромінювачем-рециркулятором «Фіолет-Т04» відмічався слабкий подразнюючий запах озону, який зникав через 15-20 хвилин. Рівень бактеріального забруднення знижувався на $31 \%$, вертаючись до початкових показників через 6-7 годин. За дворазового пропускання повітря через рециркулятори рівень бактеріального забруднення за 75 хвилин обробки знижувався майже вдвічі, проте в приміщенні з'явився сильний подразнюючий запах озону, температура повітря піднялася на $3{ }^{\circ} \mathrm{C}$. Птиця вела себе неспокійно, не приймала корм і воду.

Доволі подразнюючий запах озону свідчить, що його концентрація вище гранично допустимої (ГДК озону в повітрі робочої зони за нині існуючими нормами $-0,1 \mathrm{mг} / \mathrm{M}^{3}$. До того ж поріг відчуття людиною озону дорівнює приблизно $\left.0,01 \mathrm{mг} / \mathrm{M}^{3}\right)$. Це може досить негативно впливати на птицю. Виходячи 3 цього, ми обрали перший режим санації повітря за наявності птиці, тобто, однократну обробку повітря протягом 35-ти хвилин. 


\section{1. Визначення оптимального режиму обробки повітря}

\begin{tabular}{|c|c|c|c|c|c|c|c|c|}
\hline \multirow{2}{*}{$\begin{array}{c}\text { Час обробки } \\
\text { повітря, хв. }\end{array}$} & \multirow{2}{*}{ Об'єм, ${ }^{3}$} & \multicolumn{3}{|c|}{ Колонієутворюючі одиниці, тис./м } & \multicolumn{2}{|c|}{$\begin{array}{c}\text { Наявність озону } \\
\text { (органолептично) }\end{array}$} & \multicolumn{2}{|c|}{$\begin{array}{c}\text { Температура, } \\
\text { } \mathrm{C}\end{array}$} \\
\cline { 3 - 9 } & & до & після & $\%$ зниження & до & після & до & після \\
\hline 35 & 105 & 362 & 250 & 31 & - & + & 22 & 23 \\
\hline 75 & 210 & 359 & 167 & 53,5 & - & ++ & 22 & 25 \\
\hline
\end{tabular}

2. Моніторинг загальної кількості мікроорганізмів у повітрі досліджуваного приміщення віварію (тис. КУО / $\mathbf{M}^{3}$ )

\begin{tabular}{|c|c|c|c|}
\hline \multirow{2}{*}{ Режими санації } & \multicolumn{3}{|c|}{ Колонієутворюючі одиниці, тис. КУО/м } \\
\cline { 2 - 4 } & до санації & після санації & \% зниження \\
\hline $6^{00}-6^{35}$ & 360,6 & 257,4 & 29,5 \\
\hline $9^{40}-10^{15}$ & 309,4 & 211,8 & 31,5 \\
\hline $12^{20}-12^{55}$ & 253,8 & 176,5 & 30,2 \\
\hline $16^{00}-16^{35}$ & 213,5 & 156,9 & 21,8 \\
\hline $19^{40}-19^{15}$ & 187,6 & 132,1 & 26,5 \\
\hline $6^{00}-6^{35}$ & 348,3 & 239,2 & 31,3 \\
\hline
\end{tabular}

Після визначення оптимального режиму санації (35 хвилин) свої дослідження ми спрямували на постійне зниження бактеріального забруднення повітря приміщення віварію. Санацію повітря проводили через кожні три години; до i після обробки відбирали проби повітря й досліджували їх на загальну мікробну забрудненість. Результати досліджень подані в таблиці 2.

Аналіз результатів досліджень показав, що перед початком роботи бактерицидних опромінювачів-рециркуляторів закритого типу загальна кількість мікроорганізмів у повітрі приміщення віварію, де знаходилися перепели, перевищувала гранично допустиму концентрацію (220 тис. мт/ $\left.{ }^{3}\right)$ у 1,7 разу, тобто, становила 372 тис. мт/м ${ }^{3}$. Після п'ятої обробки повітря впродовж робочого дня даний показник знизився нижче рівня ГДК на $40 \%\left(132\right.$ тис. мт $\left./ \mathrm{m}^{3}\right)$.

Зазначений режим роботи опромінювачів ми

\section{БІБЛІОГРАФІЯ}

1. Байдевлятов Ю. А. Забруднення повітря пташників у процесі ї експлуатації [Текст] / Ю. А. Байдевлятов // Ветеринарна медицина України. - 2001. - №10. - С. 29.

2. Ветеринарно-санітарні правила для птахівничих господарств і вимоги до їх проектування / НТП-АПК №565/5756. - К., 2001. - 32 с.

3. Державні санітарні норми та правила «Гігієнічна класифікація праці за показниками шкідливості та небезпечності факторів виробничого середовища, важкості та напруженості трудового процесу»: ГН 3.3.5-8-6.6.1. - [Чинний від 2002.03.01].

4. Дуюнов E. Е. Застосування нових режимів дезінфекції для зменшення мікробної забрудненості по- опрацьовували протягом місяця. За цей період було оброблено 450 перепелів, які утримувалися в клітках.

Слід зауважити, що в процесі роботи бактерицидного опромінювача-рециркулятора птиця вела себе спокійно, добре поїдала корм і пила воду.

Після використання опромінювача кількість мікроорганізмів у повітрі досліджуваного приміщення знижувалася після кожної обробки приблизно на 28 \%, а збереженість поголів'я становила $100 \%$.

\section{Висновки:}

1. Ультрафіолетовий бактерицидний опромінювач-рециркулятор закритого типу «ФіолетТ04» за розробленими нами режимами санації не впливає негативно на птицю.

2. Обробка повітря через кожні три години (тривалістю 35 хвилин) знижує кількість мікробних тіл в $1 \mathrm{~m}^{3}$ повітря приблизно на $28 \%$.

вітря при вирощуванні бройлерів // Птахівництво: Міжвід. тематич. наук. зб. / ІП УААН. - Х., 2006. Вип. 58. - С. 38.

5. Земляной И. Ультрафиолет против микробов [Текст] / И. Земляной, А. Тищенко // Сельский журнал. -2001 . - №3. - С. 12-15.

6. Савост'янова К. В. Зниження мікробного забруднення повітря у пташниках для утримання курейнесучок [Текст] / К. В. Савост'янова, В. О. Мельник // Птахівництво: Міжвід. тематич. наук. зб. / ІП УААН. - Х., 2009. - Вип. 61. - С. 48-52

7. Чорний М. Гігієна та забезпечення профілактики хвороб тварин [Текст] / М. Чорний // Ветеринарна медицина України. - 2001. - №9. - С. 8-99. 